\title{
History as Propaganda: Swaying the Minds of Quebec Adolescents
}

\author{
Jon G. Bradley ${ }^{*}$, Sam Allison \\ Faculty of Education, McGill University, Canada
}

Copyright $\subseteq 2018$ by authors, all rights reserved. Authors agree that this article remains permanently open access under the terms of the Creative Commons Attribution License 4.0 International License

\begin{abstract}
Unlike scientific and other academic domains which have recognized international standards, the humanities are generally not governed by such acceptable overarching tenets. This lack of outside independent oversight is specifically evident within the broad arena of the social sciences and, even more particularly, with the domain of History. The conundrums of "which history" and "whose stories" become markers embedded in the societal landscape continuing to impact secondary school curriculum developers. Using the recently deposited Province of Quebec high school history program as an exemplar, the authors illustrate how a closed non-transparent anti-democratic process lead to narrow foci, public conflict, suspect subject content, and pedagogical propaganda.
\end{abstract}

Keywords Curriculum Development, Secondary History, Pedagogical Propaganda, Historical Authenticity

\section{Introduction}

While there had been many months of simmering debate, behind the scenes complaining, radio talk-show rants, and several television news features, the public's anger to the imposed new high school history program reached a peak in May of 2017 with the Canadian Broadcasting Corporations' headline: "It's not acceptable!" (1).

Capping two-years of clandestine development, the bright light of scrutiny highlighted what was clearly evident as a shallow attempt to portray Canada's history through a specific lens. Once seen in its full illumination, the reaction from Quebec's English language community, all First Nations Peoples, teachers' groups, as well as other cultural associations within and outside Quebec society, was outrage and condemnation (2-5).

This following analysis is framed by two overarching parameters: (a) the "process" of curriculum development undertaken to introduce a new high school history program rather than the actual "historical content" of the new program which the authors have addressed earlier (6-7); and (b) the overarching political reality specific to Quebec and it's perchance to "secrecy". In a recent scathing report, the official access-to-information commissioner stated that "Quebec is among the least transparent provinces in Canada" and "ranked $10^{\text {th }}$ out of 14 jurisdictions in Canada for transparency according to the Global Right to Information Rating (GRIR)" (8).

A fundamental question arises: how did this curriculum debacle come to fruition?

\section{Overview of the Canadian Educational Scene}

Unlike many other democracies, Canada does not have a federal or central ministry of education. The Canadian Constitutions (both the original British North America Act of 1867 as well as the 1982 repatriated Canadian Constitution Act) clearly and unequivocally place the responsibility for public education in the hands of each province and territory (9). The end result is a highly-fragmented country-wide education system with embedded political and social interests competing for influence.

Outside of some recent minor attempts to fund universities and other institutions of higher learning through various scholarship programs, along with a dwindling responsibility for education in First Nations/Metis/Inuit Communities, the Canadian government has little to do or say regarding the public education systems administered by the provinces and territories.

In practice, there are fourteen independent ministries of education on the Canadian educational landscape: 10 at the provincial levels, 3 for each of the territories, as well as final federal one restricting its own activities to Aboriginal education on Reservations. 
An important "odd" feature of the Canadian Constitutions is that all new remerging powers, not anticipated at the time, are automatically conferred upon the Canadian Parliament. This means, in practical terms, that the obligations and responsibilities of the various provinces and territories are "frozen" as all new elements (the Internet, cyber banking, and pipelines as but three evolving issues) fall automatically within federal authority. With this in mind, all provinces and territories jealously guard their education responsibilities as one of the few key societal obligations which they totally control and can mold without Federal oversight.

Notwithstanding this fragmentation, the many and varied education systems within Canada have generally fallen into line with what might be seen in many other countries. In fact, at first blush, the organizational structure may appear a tad common (10). For example, throughout Canada, students are required to attend public school (with slight variations for private and home schooling situations) until the age of sixteen usually comprised of 6 years of elementary school with maybe a year or two of kindergarten prior to grade 1 ( $\mathrm{K}$ to grade 6 ); followed by 5 years of secondary school (grades 7 to 11) although a few provinces offer a grade 12. Following high school, students (roughly aged 17) are theoretically able to move onto the job market or any number of trade, vocational, college, or even university programs.

All provinces establish graduation criteria for the awarding of what might be termed a "high school leaving certificate". It is this official certificate that authenticates successful completion of this level of formal schooling and is the document necessary for future studies. Additionally, the specific academic standards and particular courses for certification are also set independently by each province and territory. Therefore, different core courses may be required in one region and not in another province; likewise, more weight may be given to selected subjects over others.

A further compounding issue is language. Canada is officially a bilingual country with English and French enjoying equal weight at the federal level and in law. At the provincial and territorial levels, the place of both languages becomes embroiled in history, custom, availability, and jurisprudence. At base, citizens may be able to enroll their siblings in a public school where either language is the language of instruction; however, this ability is tempered by numbers and local regulations and is not always absolute.

This linguistic guarantee slides over into the educational sphere where provinces and territories have a legal obligation to equally fund schools that use either language of instruction. In the Province of Quebec, for example, both English and French language schools receive identical amounts of funding; however, such equality does not translate into the curriculum realm where French language orientations determine content and direction.

\section{Recent History Curriculum Conundrums}

While it is beyond the scope of this investigation to review the status of high school history curriculum development world-wide, it is indeed appropriate to identify some of the more recent pitfalls that education developers face in various jurisdictions as attempts are being made to place past events into an appropriate contemporary framework suitable for questioning adolescents. Regardless of country, many curriculum planners struggle with ways to portray past events to secondary level students and the general citizenry.

Taylor and Macintyre (11) provide an insightful overview illustrating how the high school textbook morphed from the main conveyor of the historical narrative into a more focused and less generic "politically motivated" vehicle. The authors have highlighted "three traditions" in the developmental process of secondary school texts: the conciliatory tradition, the critical tradition, and the pluralistic system. Briefly, the Conciliatory Tradition has its roots in the aftermath of World War One where the League of Nations urged that texts be as free from biases as possible. The Critical Tradition grounds itself on a pedagogical playing field where political and ideological ideas clash to (in)form an emerging national identity. The Pluralist Tradition, on the other hand, does not rely exclusively on the mandated textbook as the prime instructional resource, with classroom practitioners exploring a wide range of possible mediums and knowledge.

Notwithstanding the evolution of textbooks from the single or sole source of history knowledge to the immense possibilities postulated by the Internet, intertwined political, societal, economic, and demographic realities continue to demonstrate that history programs and texts are mired in a morass of conflicting and competing points-of-view struggling to balance the past with an emerging present. For example, curriculum planners in France continue to debate how the period in World War II known as "Vichy France" is to be portrayed (12-14). Furthermore, the (United States of America) Texas State Board of Education became embroiled in a controversy regarding the use of the word "worker" to replace "slave" in an approved textbook as well as the portrayal of Mexican immigrants (15-18).

The continuing conundrum of history education is also aptly illustrated in very contemporary situations as curriculum planners in post-civil-war Lebanon are investigating how new history textbooks might transverse a cultural void in not only dealing with a relatively recent tragic past but also foreshadow a new future (19).

While there is a growing body of knowledge regarding the overall field of history curriculum development at the high school levels (20), there is a dearth of data dealing with the processes of such initiatives. That is, how open or 
closed, what input from which groups, how might outside evaluators be employed, and what ongoing evaluative procedures continue to tweak and/or modify the course of study?

\section{Status of History in Canadian High School Curricula}

Every province and territory in Canada has a different array of subjects for the high school curriculum. While all may make, for example, "Mathematics" a graduation requirement, each may have a different level with differing amounts of instructional time. In many cases, several levels of the subject will be offered so as to satisfy both internal graduation requirements as well as requirements for so-called "advanced" and/or "international" programs. Likewise, the level of French-as-a-second-language may well be more stringent in Quebec and New Brunswick than in British Columbia and Nunavut due to time allocations, availability of competent teaching staff, community input, and other curriculum demands.

Acknowledging that the Federal Government has little sway over public school programs, periodic pleading by various federal ministers highlights this educational and jurisdictional split. Former Heritage Minister James Moore, as but one recurring example, decried the fact that "there is little the federal government can do" but he nonetheless noted "If you don't teach history in school, then there aren't going to be people going to university to learn history and then teach history, themselves. It becomes a shrinking pool of self-defeating reality" (21).

Currently, only four Canadian provinces require students to take Canadian history as part of the secondary school certification package: Manitoba, Nova Scotia, Ontario and Quebec (21-22). In other words, the remaining 6 provinces and 3 territories - comprising over one-third of Canada's population including the evolving and remote areas of Northwest Territories, Nunavut and Yukon demand no formal historical studies for their high school certification.

In Quebec, the domain of history is required in grades 9 and 10 (referred to in Quebec as secondary III and IV) comprising 100 hours of classroom instructional time per year. As an added feature, all Quebec students write a "June Uniform Examination" on the same day at the same time at the end of grade 10 with this mark contributing half of the overall grade towards this graduating requirement. (As a side note and worthy of a separate investigation, the Quebec Ministry of Education regularly "moderates" the mix of in-school marks with the June examination marks so as to maintain a respectable passing ratio.)

The student population in Quebec is not insignificant. Data from the 2014-2015 school year (the most accurate available at this time) notes that almost 400,000 students were enrolled in secondary school (23). Assuming a somewhat even distribution amongst the grade levels but accounting for normal projected demographic shifts and the relatively high drop-out rate, it can be estimated that approximately 125,000 to 150,000 adolescents annually will be directly impacted by this new history program.

\section{Quebec's Recent History Revision Process}

Until the mid-2010s, Quebec students took "History and Citizenship Education" which had only been in effect for a decade. This course of study was pedagogically awkward in that students studied major themes covering a 500-year time frame in secondary III (grade 9) and then reengaged the same issues via a chronological framework in secondary IV (grade 10) and very important examination year. The other contributing confusion was that although the course was supposed to deal with "Citizenship Education", this large topic was never questioned via the final examination (24). Therefore, there was a general understanding within the educational community that this existing course was in need of an overhaul so as to correct pedagogical weaknesses rather than its historical grounding (25).

However, citing the new need to highlight "Quebec's singular experience", thereby deliberately altering the historical canon that acknowledges that "a National Historian is one who expects that his countrymen will do great things together in the future and therefore believes that they have done great things together in the past" (26), the Quebec Ministry of Education embarked on a fast-paced process to implement a new secondary history course of study. The publicly stated goal was to "teach students through the lens of French Canada's unique travails including its struggle for nationhood" (24-25).

In order to frame the ensuing curriculum development process, the following brief time line will offer an illustrative portrait. The key factors embedded within this chronology are: (a) the history revision process commenced under one political party, (b) the basic tenets were accepted and brought to fruition under another political regime, (c) the developmental process was shrouded in secrecy, and (d) the overall effort was devoid of transparency, community input, and outside review.

\section{2:}

September: separatist leaning Parti Quebecois (PQ) gains minority status and forms provincial government and promises to "revise" the existing secondary history program so as to highlight Quebec's "unique" and "singular" past (25).

2013:

November: Consultation Document for the Reinforcement of the Teaching of Quebec History in 


\section{Elementary and Secondary School released.}

\section{4:}

April: PQ calls "snap election" and loses minority status to a Quebec Liberal Party majority (PLQ).

May: The Meaning of History [Final Report Following the Consultation on the Teaching of History] released.

June-August: draft program subjected to outside "validation". Members of this committee, their affiliations, and expertise along with their individual reports declared "confidential" by Ministry and will not be released for research purposes (official government letter to one of the authors).

September-June: draft program begins field-testing in a small number of schools. Locations and names of schools secret with participating teachers required to sign "confidentially contracts". (Teachers' responses to new program also declared "confidential" following procedure established for "validation" process as per letter to one of the authors).

\section{5:}

September: first "unofficial" drafts of proposed new program begin to appear and criticisms from various community sectors commence (27-28).

\section{6:}

Spring: responding to overwhelming criticism, Minister of Education, ignoring possible administrative chaos, suggests that school boards can stall introduction of program past September date for up to one year.

September: ignoring Minister's postponing suggestion; first year of program is formally commenced in all schools.

\section{7:}

January: Final Preliminary Version of "History of Quebec and Canada" two-year program released. Even at this late date, Ministry still insists program alterations possible (29).

August: Education Minister Sebastien Proulx officially signs new history program into law and, when questioned whether critical comments from various community groups have been integrated, simply replied that "you cannot satisfy everyone" (30).

Within this time line are buried the three (3) documents that highlight both the speed of the curriculum process as well as the lack of transparency and open dialogue with community stakeholders or even a wider academic audience.

The first official material to emerge indicating the orientation of a possible new program was Consultation Document: For the Reinforcement of the Teaching of Quebec History in Elementary and Secondary Education. Released in November 2013, there is no specific authorship, no references, no bibliography, and no list of presenters or affiliations.

Strikingly, this 23-page booklet contains no individual or committee authorship but was printed under the authority of the Ministry of Education. As such, it carries the imprimatur of the Government and stands as official policy.

The Meaning of History followed six months later in May 2014. This 64-page missive sets the curriculum tone by repeating almost verbatim the elements articulated in the earlier Consultation Document specifically highlighting the need for a "national" (Quebec centered) history course. While the booklet constantly refers to a "committee" as being the organizing structure, the names and affiliations of committee members are absent. Therefore, as in the previous document, authorship is hidden.

Following the procedure set in the earlier material, this document contains no reference or bibliographic list and appears to draw its conclusions from the framework originally set via the Consultation Document, augmented by unverified presenter briefs, and filtered through the lens of an unnamed committee.

Notwithstanding the fact that this document does list the names of the 75 individuals/groups who submitted briefs to this unidentified committee (unfortunately, many affiliations and areas of expertise of presenters are absent), all of these submissions have been declared "confidential" - again, as per letter to one of the authors - and are not available for research purposes via hard copy or Internet. As follow-up, one of the authors wrote to seven English language organizations who are listed as having input and all failed to make their briefs available.

The initial versions of the "History of Quebec and Canada" program appeared in draft and working copy formats as early as the fall of 2015. Responding to community negative reaction from several frontiers, the Government "stalled" implementation, promised revisions, asked for input, but basically forced the issue with full implementation for the secondary III cohort as of September 2016 (31).

Therefore, from the political desire of a newly elected provincial government in September 2012 to install a new curriculum, the whole of the developmental process realistically and practically took place over a span of approximately two-years during which there was not one open public meeting, no availability of briefs and submissions, and all of the organizing committee members remained shrouded in secrecy!

\section{Curriculum Conclusions}

There is a philosophical gulf between what might be included within a history curriculum (content) as opposed to how the curriculum (process) is developed. Perhaps the most recent public North American display of content 
debates played out between the American Historical Association (AHA) and the State of Texas Board of Education. Briefly, the AHA challenged several aspects of the State's history curriculum and approved textbooks (32) and requested that authorized textbooks be vetted by an independent group of professional historians. The State has refused this request and reaffirmed the current practice of having history curriculum and textbooks fact-checked by a citizen's panel (33).

Another very public spat regarding history curriculum redesign unfolded in England several years ago when the Ministry attempted to revise both the secondary history program as well as the methods of evaluation (34). In this case, after wide-spread public outcries and often energetic debate, the program was redrafted to take into account some of the raised criticisms and concerns that emanated from the open debates via public gatherings (35).

John Torpey (36) suggests that politically motivated and closed historical narratives, while often powerful vehicles, flounder when the imposed past does not offer a foreshadowing of a better future. Peter Seixas (37) cogently notes that "those who wish to use history in the schools to promote national cohesion may simply not understand that a history which makes the past problematic may dilute the simpler promotion of national identity".

As a contrast to the process employed in the Province of Quebec, the Office of Public Engagement in the Province of Newfoundland and Labrador.

"Recognizing the importance of engaging residents on a wide range of important public policy issues, it is increasingly being recognized that the process through which policy-makers reach decisions is just as important as the outcomes themselves. As such, public engagement plays a key role in the democratic process "(italics added: 38).

This Quebec history program revision, on the other hand, was developed in secret without any oversight that challenged the course developers. As a result, the ensuing course of study lacks respectability and harbors the scent of a gerrymandered program designed for narrow political aims rather than accuracy. Instead of providing the adolescents of Quebec with a secondary experience that demonstrates wide-spread consensus and acceptance, this truncated effort was shrouded in secrecy.

"The dangers inherent in the idea of democracy itself stem from isolating and promoting only one side of its ingredients. ... The people, freedom, and progress are constituent elements of a democracy, but if one of them breaks free from its relation with others...they become distinct dangers..." (39).

All citizens in a democracy must have faith in the overall educative processes employed in curriculum development. Reflection and disagreement must not only be encouraged but invited. The speed and secrecy surrounding this educational development did not embrace a transparent process and meaningful citizen engagement was dismissed for a politically motivated end goal.

\section{REFERENCES}

\section{[1] Marandola S. CBC News, May 2, 2017.}

[2] Kay, B. Quebec's history through the looking glass, National Post, May 15, 2013.

[3] Montpetit J. Why teach history? The battle over Quebec's high school history curriculum, CBC News, March 13, 2016.

[4] Green R. Quebec's rotten history curriculum is fault of both PQ and Liberals, Ricochet Media, August 30, 2016.

[5] Wilton K. Teachers parents urge more inclusive history course for Quebec students, Montreal Gazette, May 2, 2017.

[6] Allison S, Bradley J. Through the looking glass: Quebec's new textbook is deeply flawed, Dorchester Review. 2017 spring/summer: 90-94.

[7] Allison S, Bradley J. Through the looking glass: Quebec's new textbook is deeply flawed, Academia.edu, 2017 July.

[8] Plante, C. Access-to-information commissioner criticizes Quebec's transparency, Montreal Gazette, October 3, 2016.

[9] Government of Canada Justice Law Website. Constitution Acts 1867-1982,

laws-lois.justice.gc.ca/eng/Const/index.html.

[10] Spencer B, Gariepy KD, Dehli K, Ryan J. Canadian education: governing practices and producing subjects. Boston: Sense; c2012.

[11] Taylor T, Macintyre S. Cultural wars and history textbooks in democratic societies. In: Carretero M, Berger S, Grever M, editors, Palgrave handbook of research in historical culture and education. London: Palgrave Macmillan; c2017. P. 613-635.

[12] Hellman J. Memory, history and national identity in Vichy France. Modern and Contemporary France. 2001, (9/1):37-42.

[13] Pascal J. Vichys shame. The Guardian, May 11, 2002.

[14] Kay B. France finally admits its past Jew hatred. National Post. May 15, 2013.

[15] Monroe B. How Texas' school board tried to pretend slavery never happened and why your kid's school may be next. HuffPost. May 25, 2011.

[16] CBS. Rewriting history? Texas tackles textbook debate. September 16, 2014.

[17] Fernandez M, Hauser C. Texas mother teaches textbook company a lesson on accuracy. The New York Times. October 5, 2015.

[18] Isensee L. Texas textbook called out as 'racist' against Mexican-Americans. NPR Houston Public News. September 14, 2016.

[19] Hourani RB. A call for unity history textbook design in a post-conflict era: the case of Lebanon. The History Teacher. 
$2017(50 / 2): 255-284$.

[20] Carretero M, Berger S, Grever M. Palgrave handbook of research in historical culture and education. London: Palgrave Macmillan; c2017.

[21] Mickleburg R. Heritage minister wants Canadian history taught in all high schools. The Globe and Mail. October 20, 2012.

[22] Brown L. Ontario lauded for high school history curriculum. Toronto Star. January 23, 2016.

[23] Institut de la Statistique du Quebec. Quebec handy numbers: 2017. Quebec: Institut de la Statistique du Quebec; 2017.

[24] Beauchemin J, Fahmy-Eid N. The meaning of history [final report following the consultation on the teaching of history]. Quebec: Government of Quebec; 2014

[25] Woods A. Quebec history courses should be rewritten with nationalist focus, report suggests. Toronto Star, February 27, 2014.

[26] Taylor M B. Promoters, patriots, and partisans: Historigraphy in nineteenth-century English Canada. Toronto: University of Toronto Press; c1989.

[27] Shingler B. New Quebec history course falls short on First Nations. CBC News, March 11, 2016.

[28] Shingler B. Quebec shelves controversial new history course. CBC News, May 12, 2016.

[29] Shingler B. Revised Quebec curriculum includes more indigenous history, does it go far enough? CBC News, March 14, 2017.

[30] Dion-Viens D. Le nouveau cours d'histoire au secondaire approuve. Journal de Montreal. August 9, 2017.

[31] Grillo M. New Quebec history curriculum has population divided. Global News. September 2, 2016.

[32] American Historical Association. In back issues. The American Historical Review.2016 June; (121/3):xiv-xvii.

[33] Hickley S. Texas: we don't need academics to fact-check our textbooks. The Christian Science Monitor, November 19, 2015.

[34] Mansell W. England's school curriculum review sparks debate. The Guardian, October 3, 2011.

[35] Mansell W. Michael Grove redrafts new history curriculum after outcry. The Guardian. June 21, 2013.

[36] Torpey J. The pursuit of the past. In Seixas P, editor. Theorizing historical consciousness. Toronto: University of Toronto Press; 2009. p. 240-255.

[37] Seixas P. A modest proposal for change in Canadian history education. In Nakou I, Barca I, editors. Contemporary public debates over history education. Charlotte: New Age Publishing; 2010. p. 11-26.

[38] Office of Public Engagement. Public engagement guide. St. John's: Government of Newfoundland and Labrador; c nd.

[39] Todorov T. The inner enemies of democracy. Cambridge: Polity Press; c2014. 